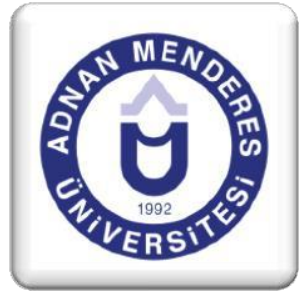

\section{Aydın İli Gözkaya Köyünde Geleneksel Halk Hukukuna Dair Örf ve Âdetler}

İsmail ABALI*

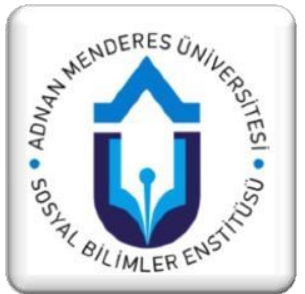

\title{
ÖZET
}

Doğası gereği sosyal bir varlık olan insan, günlük hayatının her alanında diğer birey ya da gruplarla doğrudan veya dolaylı olarak sürekli iletişim halindedir. Bu durum da kişiler arasında birtakım ilişkilerin ortaya çıkmasına neden olur. Söz konusu ilişkinin taraflara zarar vermeyen, onların hak ve çıkarlarını gözeten ve gerektiği durumlarda birtakım yaptırımlarla karşı karşıya getiren bu sosyal düzen kuralları, yani hukuk sistemi, ait olduğu topluluk tarafindan yazılı ya da yazılı olmayan biçimlerde kuşaktan kuşağa aktarılır. Yazılı olmayan ve birtakım teamül, gelenek, örf, âdet ve inanışlar temelinde teşkil olunan hukuk sistemi ise halk hukukudur. Bu çalışmada, Aydın ilinin Koçarlı ilçesine bağlı Gözkaya köyünde yaşayan bireylerin sosyal ve özel hayatlarında kişiler arasındaki ilişkileri bir düzene sokmak amacıyla bazı örf ve âdetlere dayandırarak geliştirdikleri uygulamalar tespit edilmeye çalışılmıştır. Köyün geçmişi, sosyokültürel hayatı ve folklorik yapısı ile ilgili kaynak kişilerden elde edilen bilgilerin de verildiği çalı̧̧mada, ayrıca, söz konusu örf ve âdetler bağlamında ortaya çıkan uygulamaları görselleştiren fotoğraflara da yer verilmiştir.

Anahtar Kelimeler: Hukuk, Halk Hukuku, Aydın İli, Gözkaya Köyü, Örf ve Âdetler

\section{The Manners And Customs About Traditional Folk Law In Gözkaya Village Of Aydın Province}

\begin{abstract}
As a natural social entity, a person is constantly communicating directly or indirectly with other individuals or groups in every aspect of daily life. This case leads to the emergence of some relations among the people. These rules of social order, that is, the law system, which does not harm the parties in question, which take into account their rights and interests and which, in necessary situations, face some sanctions, are transferred to the group in the form of written or unwritten forms. The law system which is not written and constituted on the basis of some convention, tradition, custom, manners and beliefs is public law. In this study, it has been tried to determine the practices developed based on some manners and customs in order to put the relations between the people in the social and private lives of the individuals living in Gözkaya village of Koçarlı district of Aydin province. In addition to the fact that the information obtained from the source people related to the village's past, sociocultural life and folkloric structure is given, photographs that visualize the practices emerged in the context of customs and traditions are also included.
\end{abstract}

Key Words: Law, Folk Law, Aydın Province, Gözkaya Village, Manners and Customs

* Dr. Öğr. Üyesi, Iğdır Üniversitesi Fen-Edebiyat Fakültesi TDE Bölümü, ismail.abali@igdir.edu.tr 


\section{Giriş}

Tarih boyunca sürekli gruplar halinde yaşayan insanların oluşturduğu toplum bir organizasyondur (Bergson, 2013: 25). Toplumu oluşturan bireyler ya da grupların sosyal refah ve bütünlük açısından bir düzene ihtiyacı vardır. İlkel toplumlarda bireyin/grubun başka bir birey ya da gruba kabul ettirdiği zorunluluklar gibi durumları bazı kurallar çerçevesinde kendi içinde çözüme kavuşturmasıyla bu düzen tesis edilmiş olur (Malinowski, 1998: 16). Tarih öncesi dönemlerden günümüze en gelişmiş toplumlarda bile halk hukuku anlayışı bulunmaktadır. Yazısı olmayan toplumlarda bütün bilgi birikimi ve teamüller sözlü olarak aktarılırken yazıya sahip toplumlarda ise iki tür hukuktan söz edilebilir: yazılı hukuk ve halk hukuku... (Dundes vd. 1994: 1-4'ten akt: Sevindik, 2013: 68)

Türkçe Sözlükte (2005: 829) "adalet; adaletin gerektirdiği ve birine ayırdığı kazanç; dava veya iddiada gerçeğe uygunluk, doğruluk; verilmiş emekten doğan manevi yetki" olarak tanımlanan hukuk, toplum içerisinde insanların birbirleriyle ve sosyal gruplarla olan ilişkilerini bir sisteme oturtan kurallar bütünüdür. Yazılı hukuk metinlerinin en eskisi olan Hamburabi Kanunları, M.Ö. 1700'lerde Babil Kralı Hamburabi'nin dikili bir taş üzerine yazdırdığı ve çeşitli konularda verdiği kararları içeren metinlerdir. Bu kararları kendisine güneş tanrısının aktardığını söylemesiyle birer tanrı sözü olarak kabul edilen Hamburabi Kanunları, hukukî ilkeleri kesin ve açık bir şekilde belirlemiştir. Bu yönüyle de yargıçların başvurabileceği temel bir kaynak haline gelmiştir. Romalılar ise daha etkili bir hukuk eseri ortaya koymuştur. "XII. Levha Kanunları" olarak tarihe geçen bu eser, Roma hukukunun temeli olmuş ve aile kurumu merkeze alınarak hazırlanmıştır. Bu kanunlar, Fransız hukukuna da ilham kaynağı olmuştur. Antik Yunan'da hukuk, filozofların öğreti konularından biri olan "ahlak" kavramı çerçevesinde ele alınmıştır. Sokrates, Platon ve Aristoteles'e göre ahlak, evrensel bir değerdir. Hukuk ise ahlakın somutlaştırılmış halidir. Ahlakın topluma yön verdiği kadar toplum da ahlakın yeni biçimler kazanmasında etkin bir rol üstlenmektedir. Avrupa'da, Orta Çağ döneminde, kilise ve kilisenin koyduğu kurallar, insanüstü bir vasıf kazanmıştır. Bu kurallar kesin ve mutlak olarak değerlendirildiğinden insanların hata yapmasının önüne geçmek için kilise tarafından tanımlanmış kurallar uygulanmıştır. Orta Çağ İslam dünyasında ise Farabi, düşünce sistemini Aristoteles'in felsefi sistemine temellendirmiştir. Ona göre insan toplumsal bir varlıktır ve mevcudiyetini korumak, iyiliğe-mutluluğa ulaşmak için diğer insanların yardımına muhtaçtır. Farabi’ye göre birey-devlet ilişkisinin temelinde mutluluğa erişme ve insanlar arasında yardımlaşmayı esas kılma anlayışı bulunmaktadır. Yeniçağa kadar kilisenin kurallarını koyduğu hukukî yaşam tarzı benimsenen Batı dünyasında, Rönesans ile birlikte birçok aydın; hukuk, toplum, devlet ve kanunlar hakkında fikirlerini açıklamışlardır. Hobbes, Spinoza, Montesquieu, Rousseau, Kant ve Marks gibi düşünürlerin de aralarında bulunduğu toplumsal felsefeciler, insanlar arasındaki ilişkinin getirdiği hukukî olgu ve sonuçlar üzerinde merkezi otoritenin, akıl ve bireysel bilincin, sosyal birlikteliğin, bireyin özgür seçiminin ve ahlakın etkilerini irdeleyerek (Dursun, 2014: 10-16) modern hukukun temellerini atmışlardır.

İslamiyet'ten önce Türkler arasında resmi hukuk-halk hukuku gibi bir ayrımdan söz etmek mümkün değildir. Çünkü hukuk, halkın babadan oğula aktardığı eski geleneklere ve Türk'ün milli şuuruyla oluşturduğu ortak akla dayanmaktaydı. Sosyal düzen, devletin de resmi hukuku sayılan bu kurallar bütünü ile sağlanmaktaydı. İslam dininin Türkler arasında yayılmasından sonra ise hukuk sistemi ikili bir yapıya bürünmüştür. Bir yanda İslam dininin getirdiği şer'i hukuk, diğer yanda da eski Türk âdet ve gelenekleriyle yoğrulmuş örfi hukuk toplumda uygulanmaya başlamıştır. Fakat Türkler arasında şer'i hukuk hiçbir zaman tamamıyla kabul görmemiştir. Devlet yönetiminde ve halkın günlük yaşantısında İslami kurallara dayanan dini hukuk kadar halk hukuku da uygulanmaya ve yaşatılmaya devam 
edilmiştir. Müslüman Türk devletlerinde birlikte uygulanan şer'i ve örfi hukuk, Osmanlı devletinde, Tanzimat ve Meşrutiyet dönemlerinde Batı hukukunun kabul edilmesiyle resmiliğini kaybetmeye başlasa da etkisi sürdürmüş; Türk hukuk sisteminde üçlü bir yap1 görülmüştür. Cumhuriyet'in kurulmasıyla Batı hukuku temelleri üzerine oturtulan Türk hukuku, zaman geçtikçe toplumun ihtiyaç ve özelliklerine uygun hale getirilmiştir (Önder, 1976: 226).

Her ne kadar Batı hukuku ile toplumsal düzen sağlanmaya çalış1lsa da günümüzde, eski Türk töresi ve gelenekleriyle oluşturulmuş örfi hukukun etkisi hala devam etmektedir. Yasalarda karşıllı̆ı olmayan durumlarda toplumun özelliklerine göre karar verme yetkisi, anayasa tarafından yargıçlara ve adli makamlara verilmiş bir inisiyatif aracıdır. Bir başka deyişle Batı hukukunun Türk toplumsal yaşamına yetmediği durumlarda örfi hukuk, belirleyici bir konumda bulunmaktadır. Bunun yanında gerek devletin yargı sisteminin işleyemediği gerek de halkın adli makamlara ve kolluk güçlerine intikal ettirmekten kaçındığı -özellikle- kırsal kesimlerde tezahür eden halk hukuku, içinde bulunduğu toplumun kurallar bütünüyle oluşmuş bir mekanizmadır.

Toplum düzenini sağlamak, bireysel ve içtimai hakları korumak, sorumlulara verilen ödevleri kontrol etmek gibi amaçlarla ortaya çıkan kurallar, hukuk sisteminin temelini oluşturur. İster yazılı ve dayatmacı bir şekilde konulmuş isterse yazılı olmayan yollarla ve toplum bünyesinde kendiliğinden tezahür etmiş olsun söz konusu bu kuralların işleyişi, kesinliği ve kalıcılığı üzerindeki en büyük etken -şüphesiz- yaptırım gücüdür. İşlenen suçun topluma ya da bireye zarar verici özelliği ile doğru orantılı olan yaptırımlar, sosyal düzenin tesisi ve bu tesisin devamlılığı konusunda caydırıcı bir nitelik taşımalıdır. Tarihi dönem, coğrafya ve toplumlara göre farkl1lık arz etmekle beraber çoğu hukuk sisteminde ölüm, müebbet, vatandaşlıktan çıkarma, süreli hapis ve para cezası gibi yaptırım türleri bulunmaktadır. Halk hukuku bağlamında ise bu yaptırım türlerinin en önemlisi "ayıplama"dır. Ayıplama; töre, örf, âdet, gelenek ve görenek gibi sosyal normların etkinliğini kalıcı tutmak için ortaya çıkan yaptırımlardan biridir.

Toplumsal yaşam, bireyler ve topluluklar arasındaki ilişkinin düzenli bir biçimde sürdürülmesi gayesiyle birtakım beklentiyi, kalıplaşmış davranışı, sosyal alışkanlıkları ve yasakları gerektirmektedir. Sosyal normlar olarak bilinen bu düzenleyici ve kontrol edici mekanizmanın unsurları arasında örf ve âdetler de bulunmaktadır. Arapçadan dilimize geçen "örf” sözcüğü, kelime anlamıyla "âdet", "hüküm", "gelenek" yerine de kullanılmaktadır. Örfler, toplumun beklentileri olarak nitelenen örnek tutum ve davranışlar bütünüdür. Örflerin birey-birey ve birey-toplum ilişkileri bağlamında sosyal düzeni sağlamak gibi önemli bir işlevi bulunmaktadır. Örflere karşı gelme, çoğu toplumda yasaları çiğnemekle bile eşdeğer tutulmuştur. "Âdet" kelimesi de Arapça kökenli olup "Alışılmış şey" manasıyla kullanılmaktadır. Yaptırım gücü örfe göre daha esnek olan âdetlerin de temel işlevi sosyal ilişkileri düzenlemek ve denetlemektir. Âdetler daha çok aile, cemaat, komşuluk, örgütlülük ya da herhangi bir topluluğun mensuplarınca yaptırımlar yoluyla uygulanması ve riayet edilmesi zorunlu hale getirilen hareket ve tavır biçimi olarak algılanmaktadır (Örnek, 1995: 121-125).

\section{Aydın İli Gözkaya Köyünde Halk Hukuku}

Aydın ilinin Koçarlı ilçesine bağlı Gözkaya köyü (Şekil-1), dört mahalleden oluşan ve 218 nüfusa sahip bir yerleşim yeridir. Aydın'a 24, Koçarlı'ya ise $22 \mathrm{~km}$ uzaklıkta bulunan Gözkaya köyü, Menteşe dağlarının uzantıları üzerinde kurulmuştur. 1995 yılına kadar eğitim-öğretim faaliyetlerinin gerçekleştirildiği, fakat 1996'dan itibaren taşımalı eğitimle 
öğrencilerinin Çakırbeyli köyüne yönlendirildiği köyde ve mahallelerinde toplam 2 ilkokul ve 2 cami bulunmaktadır. Temel geçim kaynağı zeytincilik olan köylü, ayrıca büyük ve küçükbaş hayvan yetiştiriciliği de yapmaktadır. Son yıllarda devlet tarafından kendilerine tahsis edilen fistık çamı bakım ve üretimi de köylülerin bir başka geçim faaliyetlerindendir. Bunun yanında bazı köylüler, kendi bahçelerinde yetiştirdiği domates, salatalık, biber, bamya gibi sebzeleri; erik, incir, kayısı, şeftali, üzüm gibi meyveleri ve hayvanlarından elde ettiği yoğurt, süt, peynir, çökelek, tereyă̆ı, yumurta gibi ürünleri de Çakırbeyli köyü, Koçarlı ilçesi ve Aydın il merkezinde kurulan köylü pazarlarında satarak gelir elde etmeye çalışmaktadır. Zeytincilik ise köylünün en temel geçim kaynağıdır. Güz aylarında zeytin hasadı ile uğraşan köylüler, bahar aylarında ise zeytin ağaçlarına bakım yaparak bir sonraki y1l ürünün verimli olmasını amaçlamaktadır. Zeytin ağaçlarından elde edilen zeytin ve zeytinyağının bir kısmını kendileri için saklayan köylüler, kalanını ise yıl içerisinde kısım kısım ya da toptan satarak ihtiyaçlarını giderirler. Zeytincilikten yalnızca zeytin ve zeytinyağ 1 elde edilmemektedir. Zeytinyağının tortusundan sabun, küspesinden hayvanlara yem, odunlarından ise yakacak elde eden köylüler, bu ürünleri kendileri de kullanabildiği gibi bahsedilen pazarlarda satmak suretiyle para da kazanabilmektedir.

Başka köylerden gelin olarak gelen bazı kadınlar hariç olmak üzere Gözkaya köyünde yaşayan herkes Yörük'tür (K1，K7). Gökbel'in $(1998,70)$ tespitlerine göre köylülerin tamamına yakını Varsak Yörüklerine mensuptur. Bazı kaynak kişiler (K2, K11) bunu doğrulasa da köylülerin bir kısmı, kendilerini Narıncalı Yörük'ü olarak tanımlamaktadır (K5, K6, K10). Kaynak kişilerin bazıları ise Karaçakal Yörüklerinden olduklarını savunmaktadır $(\mathrm{K} 4, \mathrm{~K} 8)$. Köye ilk olarak ne zaman ve nereden geldikleri hakkında herhangi bir bilgi sahibi olmayan köylüler, dedelerinin köy merasında bulunan Çukurköy ve Çökek mevkilerinde bir müddet ikamet ettiklerini bilmektedir (K6, K8). Bu alanlarda bulunan ve tarafimızca tespit edilip okunan bir mezar taşının 1831 tarihli olması, Yörüklerin Gözkaya köyüne olmasa bile bu yöreye gelişinin en az 200 yıl önceye dayandığı konusunda izlenimler vermektedir. 25-30 yıl öncesine kadar yazın yaylaya göçtüklerini, kışın da Gözkaya köyünde oturduklarını ifade eden köylüler, günümüzde ise bu uygulamaya son vermiş ve tamamen yerleşik yaşama geçmişlerdir.

Köylülerin geçmişinin Yörük kültürüne dayanması ve köyün şehir merkezlerine uzak bir konumda bulunması gibi etmenler, Gözkaya köyünde kültürel hayatın ve folklorik yapının canlı kalmasını sağlamıştır. Atalarından kalan eski gelenek ve uygulamalarına sıkı sıkıya bağlı olan köylüler, bu örf ve âdetlerini özellikle geçiş dönemlerine bağlı bazı törenlerde yaşatmaya çalışmaktadır. Doğum olayına bağlı kırklama, ad verme, duşak kesme, aydaş aşı pişirme, ilk diş, kulak delme ve sünnet; evlenme ile ilgili isteme, söz kesme, nişan, yanık, düğün ve duvak; ölüm ve etrafında gelişen yıkama, gömme, hayır yapma, yas tutma törenlerinde söz konusu inanış ve uygulamalara rastlamak mümkündür. Geçiş dönemlerine bağlı törenlerin yanında yağmur duası ve hayvan sağaltma merasimlerinde de birçok halk bilgisi ürünü ile karşılaşıllmaktadır. Köyün sınırları içindeki dede mezarlarının (yatır) yakınında gerçekleştirilen söz konusu bu törenler, köydeki folklorik canlılığın temel yapı taşlarındandır. Köyde folklorik yapının etkililiğini geçim kaynakları ve faaliyet alanlarının tezahüründe de görmek mümkündür. Temel gelir kaynağı zeytincilik olan köylü, yıl boyunca zeytin ağacı ve ondan elde ettiği ürünlerle meşgul olmaktadır. $\mathrm{Bu}$ durum da çiftçilerin zeytincilikle ilgili geleneksel yöntem ve uygulamalar geliştirmesine neden olmuştur (Abalı, 2014: 115-139).

İslam öncesi Türklerde devlet düzenini, sosyal ilişkileri ve günlük yaşamı tanzim eden "töre", "bozkır kültürü" gibi kavramların günümüze yansıması olarak değerlendirilen "halk hukuku", Gözkaya köyünde de eskiden beri uygulanagelen geleneksel yöntemlerle vücut 
bulmaktadır. Köyde yaşayan her bireyin riayet etmeye özen gösterdiği, ailesine ve oğullarına öğrettiği bu hukuk kuralları, yaptırımları manevi yönden güçlü ve etkili kurallardır. Özellikle hayvancılık ve zeytincilik ile ilgili uygulamalar bu yönden kayda değerdir. Çünkü köyde, gelir kaynaklarının kullanımı ve paylaşımı ile ilgili kuralların çiğnenmesinin cezası 35-40 yıl öncesine kadar ölümdü. Günümüzde ölüm ve fiziksel şiddet gibi cezaların görülmemesine rağmen eskiden karşılaşılan bu yaptırım gücünün verdiği korku, bugün söz konusu kaynakların kullanımı ile ilgili kurallara bireylerin daha çok özen göstermesine neden olmaktadır. Gelir kaynakları ile ilgili hukuk kuralları dışındaki uygulamaların en büyük yaptırımı ise "ayıplama" ve bu ayıbın yayılmasıdır. Manevi yönden büyük bir ceza kabul edilen ayıplanma, köyde yaşayanların karşılaşmak istemediği bir durumdur ve bu sebeple herkes "Dedelerimizden böyle gördük", "Yol, yordam var" sözleriyle nitelediği günlük yaşama dair kurallara uymaya özen gösterir. Öyle ki bu kurallara uymamanın getirdiği yaptırımlar bazen ayıplanma ile kalmayıp kişiye çiğnediği örf ve âdetle ilgili lakap takılması ve ailesinin nesiller boyunca köyde o lakap ile anılmasına kadar varabilmektedir ${ }^{1}$.

\subsection{Sosyal Hayat İle İlgili Örf ve Âdetler}

\section{a. Hayvancılıkla İlgili Örf ve Âdetler}

* Gözkaya köyünde koyun, keçi ve sığır cinsinden hayvanlar, bașka sürülere karıştığında ayırt edilebilmesi ya da kaybolduğunda rahat bulunabilmesi açısından sahibinin belirlediği bir yöntemle işaretlenir. Yörede bu işaretleme işlemine "enneme ${ }^{2}$ " denir. Koyun ve keçinin ennenmesi için kullanılan iki farklı yöntemden ilki hayvanın kulağının kesilmesi işlemidir. Bu işlemde hayvanın kulağı enine veya dikine kesilir. Enine kesilen kulağın bir parçası kopartılıp atılır ve bu sayede hayvanın daha sağlıklı olacağına da inanılır. Dikine kesme işlemine ise "dilme" adı verilir. Hayvan sahipleri, hayvanların tek kulağını ya da her ikisini de bu yöntemle keserek hayvanın kendisine ait olduğunu herkese bildirir ve hayvan kaybolduğunda başkalarına bu şekilde tarif ederek bulunmasını da kolaylaştırmış olur. Kulak kesme işlemi, aynı şekilde sığır cinsi hayvanlar için de kullanılmaktadır (Şekil-2). Koyun ve keçinin işaretlenmesinin bir başka yöntemi ise hayvanı boynundan ya da kalçasından boyama işlemidir (Şekil-3). Bu işlem için de mavi, yeşil ve kırmızı boyalar tercih edilir (K1, K6).

* Köylüler, köy merasında yakalanan başka köyün hayvanlarını "tokat" (Şekil-4) adı verilen bir alana hapsederler. Diğer köylülere ait hayvanların Gözkaya köyü otlaklarında görülmesi ile muhtarın görevlendirdiği birkaç genç, hayvanı yakalayıp tokada getirir. Muhtar, diğer köylere kendi meralarında bir hayvan bulunduğu yönünde haber gönderir. Hayvanın sahibi Gözkaya köyüne gelip bir miktar para ödedikten sonra hayvanını teslim alır. Hayvan sahibi bir iki hafta içinde gelmezse hayvan ya satılıp parası köy sandığına aktarılır ya da (eti yenen bir hayvan ise) kesilerek eti köylüye dağıtılır. Tokada sadece yabanc1 hayvanlar değil köyde yaşayan bir kişinin hayvanı da hapsedilebilir. Kendi bahçesine ya da

\footnotetext{
${ }^{1}$ Bu lakapların birkaçı: On beş okka yă̆ kaldıranlar: Bu lakabın takıldığı ailenin büyüklerinin, eskiden başkasına ait birkaç zeytin ağacını hasat edip on beş kilo yağı haksız yere zimmetine geçirdiği rivayet edilir. Bedavacılar: $\mathrm{Bu}$ lakabın sahibi olan ailenin bir büyüğünün, yetim bir kızı bilezik takmadan oğluyla evlendirdiği yönünde söylentiler vardır. Ĕ̆ri Boyun: Bu lakabın sahibi ise anlatılanlara göre satın aldığı ineğin yavrusunun boynu eğri olduğunu iddia ederek "çoban salık" vermeyi reddetmiştir.

2 "Enlemek", "enemek", "eñemek", “en vurmak" şeklinde de ifade edilen bu uygulamaya Afyon, Isparta, Muğla, Konya ve Aydın'ın bazı ilçelerinde de rastlanmaktadır (BKZ. Derleme Sözlüğü V, 1993: 1750).

${ }^{3}$ Tokat, gelip geçenlerin görebilmesi için köyün meydanına yakın bir yerde kurulan, etrafı duvarlarla örülü bir alandır (BKZ. Derleme Sözlüğü X, 1993: 3947).
} 
tarlasına giren hayvanı yakalayan köylü, hayvan sahibiyle anlaşmaya çalışır. Anlaşamazsa hayvanı tokada götürerek muhtarı devreye sokar (K7, K8, K11).

* Satın alınan koyun, keçi, inek gibi hayvanların fiyatına ek olarak ev hanımına, çocuğa ya da hayvanları yetiştiren başka bir bakıcıya/çobana küçük bir miktarda "çoban salı $^{4}$ " verilir. Satın alan kişi, çoban salığ 1 vermeyi unutursa bu durum hatırlatılır. Çoban salık vermeden alınan hayvanın bereketsizlik getireceği inanışı vardır $(\mathrm{K} 6, \mathrm{~K} 7)$.

* Satılan at ve eşek gibi yük hayvanlarının yuları, kolanı, urganı ve semeri hiçbir şekilde satılmaz. Satın alan kişi de bu kuralı bilir ve teklif dahi etmez (K2).

* Kendi tarlası içerisinde yuva yapmış bir arı sürüsünü bulan kişi, köyde arıcılık yapan birisini çağırır. Arıcı, yabani arı sürüsünü kendi kovanına alır ve arının yapmış olduğu petekli bal1, sürüyü bulan kişiye hediye eder (K6).

* Yeni doğan buzağılara bakarken "Maşallah" ya da "Gözüm dağlara, taşlara" demeyen kişi o esnada korkutulur. Bu korkutma esnasında her türlü yalan söylenebilir: "Önünde y1lan var", "Arkandan domuz geliyor" gibi... (K1)

* Yeni doğan hayvana bakarken nazarı değeceğinden şüphelenilen kişinin gözüne yeşil bir yaprak yapıştırılması gerekir. Bu durumun karşı tarafı kırabileceği ihtimali olduğundan yeşil yaprak onun fark edemeyeceği şekilde elde de tutulabilir. (K1).

* Yaylaya ilk kez çıkıldığında koyun/keçi sürüsünün içinden yabancı bir kişinin geçmesine izin verilmez. Aksi takdirde sürünün doğurganlığının azalacağı ve ölüm oranının artacağına inanılır. Geçmek isteyen kişiye bu durum anlatıldığında genellikle makul karşılanır (K1, K10).

\section{b. Çiftçilikle İlgili Örf ve Âdetler}

* Köylülerin büyük bir bölümü, zeytin ağaçlarını tel ya da taş duvar ile çevrelemez. Çünkü zeytinler, hayvanların zarar veremeyeceği bir yüksekliktedir. Herhangi bir sınır olmadığından dolayı da bazı çiftçiler yanlışlıkla başkasının zeytin ağacını hasat edebilmektedir. Bu durum fark edildiğinde kişi, hasat ettiği ürünün ederi kadar sahibine ücret öder ya da bedeli kadar zeytinyağı verir. Bunların yanında, ağız tatlılığı bozulmasın diye bir tabak da bal hediye eder. Bu gibi karışıklıkları önlemek için bazı çiftçiler ise ağaçların gövdesini mavi boyayla boyayabilirler (K6).

* Zeytinliğin sınırındaki ağaçlardan çırpılan zeytinlerin bir kısmı, başkasının ağacının dibine gidebilir. Bu yüzden zeytinler, sırıklarla aksi yönde çırpılır. Yine de başkasının ağacının dibine gitmişse toplanmaz. Sahibine ayıp olmasın diye ağacın dibinde birak1lır (K5).

* Bazı zeytinlik sahipleri, zeytinlerin hasat ve bakım işlerini başkalarına yaptırabilir. $\mathrm{Bu}$ uygulamada ise farklı yöntemler bulunmaktadır. Yarıya adı verilen yönteme göre ürünün hasadından elde edilen yağ ya da para, zeytinliğin sahibi ile hasadı yapan arasında eşit olarak paylaştırılır. Bu yöntemde zeytinliğin bakımı da hasadı yapan kişiye aittir. Tohur denilen yöntemde ise hasatçının zeytinliğin bakımı ile ilgili hiçbir sorumluluğu yoktur. Bu yöntemde zeytinlik sahibi, hasat mevsiminden evvel belli bir ücret karş1lığında ürününü hasatçıya satar. Zeytin hasat edildikten sonra tüm geliri hasatçıya aittir. Gelirin verilen ücretten az ya da çok olmas1 durumunda taraflar birbirinden hak iddia edemezler (K2, K6).

\footnotetext{
${ }^{4}$ Aynı uygulamaya "salık" adıyla Denizli ve Isparta'da da rastlanmaktadır (BKZ. Derleme Sözlüğü X, 1993 :
} 3526). 
* Eski Türkler arasındaki yağmalı toy (potlaç) geleneğinin bir yansıması olarak düşünülen (Dursun, 2014: 198) ve eski bir Türk ziraat geleneği olarak gösterilen (Ögel, 1978:30) başak kültürü Gözkaya köyünde de korunmaktadır. Aynı köyde yaşayan ya da başka köylerden gelen yoksul aileler, zeytin hasadını bitirenlerin zeytinliğine sahibinden izin almaksızın gidebilmekte ve hasattan sonra ağacın başında ya da dibinde kalan zeytinleri toplayıp satarak gelir elde edebilmektedir. "Başaklama" ve "başağa gitme" olarak adlandırılan bu yardımlaşma usulü, zeytinlik sahibinin hasadı bitirdiğini köye ilan eden "kurtuluş tüfeği atması ${ }^{5 "}$ " ile başlamış olur (K1, K4).

* Köyde, zeytincilik faaliyetleri esnasında uygulanan "ödek kültürü" mevcuttur. Bu uygulamaya göre zeytin çuvallarını yola taşıyabilmek için yük hayvanı bulunmayan kişiler, köydeki diğer kişilerden ödünç eşek veya katır isterler. Buna karşılık kişi, hayvanın yıpranma payı olarak eşek için bir, katır için de iki gün olmak üzere hayvanı ödünç aldığ kişinin zeytin işine bedelsiz yardıma gider. Bu uygulamaya "ödek" ya da "ödeğe gitme" denir $(\mathrm{K} 1, \mathrm{~K} 11)$.

* Çiftçilikle geçinen köylülerin en büyük gelir kaynağı zeytinciliktir. Zeytinliği olmayan aileler ise güz ve kış aylarında işçi olarak başkalarının zeytinliğine giderler. Zeytin toplarken birbirine yapışık halde bulunan zeytinin çekirdeği kurutulur (Şekil-5) ve zeytinlik sahibine verilerek karşılığında bahşiş alınır. Zeytinlik sahibi bu çekirdeği alıp cüzdanına koyar. Çünkü bu çekirdeğin bereket getireceğine inanılır. Zeytinlikte uygulanan bu durum pamuk işçiliğinde de görülmektedir. Pamuğun da çukur yapraklısı bereket demektir. Çukur yapraklı pamuğu bulan işçi, bunu dayıbaşıya ${ }^{6}$ vererek karşıllı̆̆ında bahşiş umar. Dayıbaşı da aynı şekilde bu pamuğu tarla sahibine verir ve bahşişini alır (K4, K7).

* İslam dininde mevcut olup olmadığı hala tartış11ıyor olsa da halk arasındaki göz hakkı kavramı, Gözkaya köyünde, özellikle çocuklar için canlı bir şekilde korunmaktadır. Çoğunlukla meyve bahçeleri söz konusu olduğunda karşımıza çıkan göz hakkı uygulamalarında birtakım kaideler de bulunmaktadır. Bunların en başında, meyvenin koparılıp ağacın gölgesinde yenmesi kuralı gelmektedir. Meyve toplanıp başka yere götürülürse bahçe sahibi tarafından bu durum hoş karşılanmaz. Meyve ağacının dallarının bahçeyi sınırlayan duvarlardan dışarı sarkması da göz hakkını doğurmaktadır. Yoldan geçen yetişkin ya da çocuklar, bu meyvelerden dilediği kadar toplayıp yiyebilir. Göz hakkı sadece meyveler bağlamında değil diğer yiyecek ve içecekler için de uygulanabilmektedir (K7, K8).

\section{c. Misafirlik Kültürü İlgili Örf ve Âdetler}

* Eve gelen misafirin gördüğü, kokusunu aldığı ve bu durumda canının çekebileceği ya da köyde bulunmayan yiyecek-içeceklerden misafirlere ikram edilmesi gerekir. Gözkaya köyünde söz konusu ikramların yapılmamasının duyulması büyük bir ayıp olarak karşılanmaktadır. Bu sebeple ev sahipleri göz hakkına riayet etmeye büyük özen gösterirler (K7).

* Gözkaya köyünde, ev sahibi konumunda bulunan tüm fertlerin misafir olarak gelen kişilerin her birine ayrı ayrı "Nasılsınız?" şeklinde sorular sorarak onlarla birkaç dakikalık

\footnotetext{
${ }^{5}$ Zeytin hasadını bitiren çiftçi, tüfeğiyle evinin önünden 7-8 el havaya ateş eder. Bu işlemin temel amacı kutlama yapmak ve diğer çiftçilere hasadı bitirdiğini duyurmaktır. Kurtuluş tüfeği atılmasının ardından bu haber bütün köye yayılır ve yoksul aileler de başak işlemi için hazırlık yapar (K1, K5).

${ }^{6}$ Yörede pamuk tarlası sahipleri, işin başında bulunamadığı için köyde tecrübeli bir kimseyi işçi bulması ve pamuğunu hasat etmesi için görevlendirir. Bu kimseye "dayıbaşı" denir. Dayıbaşının işçilerin performansını takip etme ve ürünün verimini yitirmeyecek bir şekilde hasat edilmesi gibi sorumlulukları bulunmaktadır (K1).
} 
özel sohbet etmesi gerekir. Aksi durumda ev sahiplerinin misafirlikten memnun kalmadığı izlenimi doğabilmektedir (K1).

* Gözkaya köyünde köy içinden ya da köy dişından gelen bütün misafirlere ne içeceklerini sormadan çay ikram edilir. Çay ikram etmeden ne içmek istediklerini sormak ayıp kabul edilir. Çaylar içildikten sonra ise yemek, kahve veya başka ikram isteyip istemedikleri sorulabilir. İkramlar misafir geldikten ortalama bir saat sonra yapilır. Daha erken ikram yapmak misafirin bir an önce gitmesini istemek olarak algılanabilir (K7).

* Gözkaya köyünde eve gelen misafirlerin ayakkabıları geldikten bir müddet sonra düzenlenir. Misafir gelir gelmez ayakkabılarını düzenlemek, ev sahibinin misafirlerin hemen gitmelerini istediği ya da ziyaretlerinden memnun kalmadığı şeklinde yorumlanır (K7).

\section{d. Diğer Örf ve Âdetler}

* Halk hekimliği uygulamalarında görülen ve bazı kimselerin sağaltıcı oldukları inanışına dayanan ocakçılık ${ }^{7}$ Gözkaya köyünde de görülmektedir. Bazı hastalıkları iyileştirdiklerine inanılan bu kimselere, Gözkaya köyünde "eli yiğni ${ }^{8 ”}$ "adı verilir. Çoğunlukla karın ağrıları, siğil geçirme, iğne vurma, nazar ayıklama, burun kanamasını durdurma gibi tıbbi ve büyüsel tedavilerine karşı1ık bu kişilere "el yiğniliği" adı verilen hediyeler götürmek gerekmektedir. Bu hediyeler çoğunlukla para, mendil, çorap, zeytinyağı ya da evde üretilen hayvansal gıdalar (süt, yoğurt, peynir, çökelek) olabilmektedir. Eli yiğni, eğer bayılan bir kişiyi tedavi ediyorsa eline bakır bir çanak ile bıçak verilir. Eli yiğni, bunları birbirine sürterek kişiyi ayıltır. Çanak ile bıçak da eli yiğninin hakkı sayılır (K6, K11).

* Gözkaya köyünde gerek ihtiyaçtan gerek de keyif almak amaçlı gençler ve yetişkinler sik sık ava giderler. Avlar bireysel olabileceği gibi topluluk halinde de olabilir. Kalabalık gidilen avlarda avcılar, birbirinin önüne geçemez. Herkesin aynı hizada, geniş bir alanda ilerlemesi gerekir. Bu kuralı bozan kişinin hem av hayvanını kaçırma ihtimali olduğuna hem de diğer avcıların kısmetinin önüne geçtiğine inanılır (K5).

* Nadir de olsa Gözkaya köyündeki düğünlerde seyirlik oyunlar oynanmaktadır. Bu oyunlardan Arap Oyunu ${ }^{9}$ ve Oğlan Mehmet-Kız Ayşe ${ }^{10}$ oyunlarında kılık değiştiren oyuncuların seyircileri kızdırmak için her şeyi yapma hakkı vardır. Seyirciler de aynı şekilde oyuncuları kızdırıp dövebilmektedir. Köyde bu durum tamamen bir eğlence unsuru olarak görülür ve kimse birbirine kin gütmez. Çocuk oyunlarından Kad1-Çavuş ${ }^{11}$, Sopalı Ebe ${ }^{12}$ ve

\footnotetext{
${ }^{7}$ Daha fazla bilgi için BKZ. (Boratav, 1973: 137).

8 "Yeğni” sözcüğü, Derleme Sözlüğünde (XI 1993: 4225) "hafif” anlamındadır. "Eli yiğni” ise yörede "eli hafif”, "eli şifalı", "eli sağaltıcı" anlamlarında kullanılmaktadır.

${ }^{9}$ Arap oyununda bir kadın, erkek kılığına girerek yüzünü siyaha boyar ve adının "Arap" olduğunu ilan eder. Meydanda absürt davranışlar sergileyerek izleyicilerin gülmesini sağlar. Bazen de izleyicilere sataşarak onları kızdırır. Arap, gözüne kestirdiği bir kadını kaçırmaya çalışır. Bu esnada elindeki sopa ile kendisine karşı koymaya çalıșanları dövebilir. İzleyiciler de Arap'ın kaçırdığı kadını kurtarmak için kendisini dövebilir (K10).

${ }^{10} \mathrm{Bu}$ oyunda bir erkek kadın kılığına girerek adının "Kız Ayşe”, bir kadın da erkek kıyafetlerini giyerek adının "Oğlan Mehmet" olduğunu ilan eder. Oyuna göre Oğlan Mehmet ile Kız Ayşe karı kocadır ve düğüne eğlenmeye gelmişlerdir. Meydana geldikleri sırada izleyicilerden biri Kız Ayşe’ye laf atar ve Oğlan Mehmet, düğün sahibinden tüfek isteyerek karısına laf atanları vurmaya çalışır. Tüfeği sopa gibi de kullanan Oğlan Mehmet bir yandan da izleyicileri oynamaya kaldırır (K10).

${ }^{11}$ Kad1-Çavuş oyunu çocuklar arasında kibritle oynanan bir oyundur. Çocuklar sırayla kibriti yere atar ve dik atan kadı, yan atan çavuş ve düz atan da hırsız olur. Kadı, hırsıza ceza vermesi için çavuşu görevlendirir. Bu ceza da çoğunlukla tokattır (K9).

${ }^{12} \mathrm{Bu}$ oyunda oyuncu sayısından bir eksik olacak şekilde daireler çizilir. Bu dairelerden biri ebenindir. Çocuklardan biri, ebenin sopasını uzak bir yere firlatır. Ebe sopasını alıp gelene kadar çocuklar, ebenin dairesini sopa derinliğinde kazmak zorundadır. Ebe geldiğinde kazamamış iseler herkes bir dairenin içine girer. Dışarıda bir kişi kalır ve bu da ebeden dayak yememek için kaçmak zorundadır (K9).
} 
Zımbır Zımba ${ }^{13}$ oyunlarında da oyunun kuralları gereği çocuklar birbirini dövmekte ve bu durum bazen ciddi yaralanmalara dönüşmektedir. Fakat hem çocuklar hem de aileleri bunun bir oyun olduğunun farkındadır (K1, K5, K10).

* Gözkaya köyünde kendisine müjdeli haber getiren kişiye "muştuluk" verilir. Muştuluk, bir miktar para olabileceği gibi mendil, çorap, gömlek, şapka gibi hediyeler de muştuluk sayılmaktadır (K11).

\section{2. Özel Hayat İle İlgili Örf ve Âdetler}

\section{a. Doğum İle İlgili Örf ve Âdetler}

* Gözkaya köyünde, günümüzde, doğumlar ulaşım kolaylığı sayesinde il merkezinde, hastanelerde yapılabilmektedir. Fakat eskiden hem ulaşım araçlarının bulunmaması hem de köprü olmadığından dolayı Çine çayının geçilmesinin zor olması nedeniyle doğumlar köyde yapılmakta idi. Bu nedenle köydeki yaşlı kadınlar, doğum yaptırma işini üstlenmek zorunda kalmıştır. Doğumu başarılı bir şekilde yaptıran bu kadınlara ise bazı hediyeler vermek gelenek haline gelmiştir: mendil, çorap, şalvar, ayakkab1... (K1)

* Köyde, yeni doğan bebeğe adını genellikle köyün imamı, öğretmeni, aileden okumuş birisi ya da aile büyüklerinden bir ihtiyar verir. Sağ kulağına ezan okunup sol kulağına kamet getirilen çocuğun kulağına da üç defa adı söylenir. Çocuğa bakıp "Adını ben koydum, yaşını Allah versin" diyerek adını koyan bu kişiye çorap, mendil, gömlek, pantolon gibi hediyeler verilir (K7, K10).

* Yürüme çağına geldiğinde çocuğun kolayca yürüyebilmesi için "duşak kesme" (Şekil-6) ritüeli uygulanır. İki ayağına iplik bağlanan çocuk, ekmek tahtasına oturtulur ve ekmek bıçağıyla "Allah ayak, demir dayak" sözleriyle duşağı kesilir. Üç kez tekrarlanması gereken bu işlemi gerçekleştirmesi için hızlı koşması ve çevikliğiyle tanınan biri tercih edilir. Çocuğun duşağını kesen bu kişiye de yine çorap, mendil, gömlek gibi hediyeler verilir (K1, K2). (K6).

* Çocuğun çıkan dişini ilk gören kişiye mendil, çorap, gömlek gibi hediye verilir

\section{b. Evlilik İle İIgili Örf ve Âdetler}

* Yalnızca evlenen iki gencin değil söz, nişan, yanık ${ }^{14}$, düğün, duvak ${ }^{15}$ ve sonraki süreçlerde ailelerin de bir araya geleceği evlilik kurumunun sağlam temeller üzerine

\footnotetext{
${ }^{13} \mathrm{Bu}$ oyunda ebenin bir dairesi vardır. Ebelikten kurtulmak isteyen çocuk, tek ayağı yukarı şekilde diğer oyunculara dokunmaya çalışır. Ebenin dokunduğu oyuncu yeni ebe olur ve ebenin dairesine girene kadar dayak yer. Ebe eğer dairenin dışında iki ayağıyla yere basarsa yine diğer oyuncular tarafindan tekme ve yumruklarda dövülür (K9).

${ }^{14}$ Yanık töreni, nişandan sonra kızla oğlanın görüşmesi ve ailelerin kaynaşması amacıyla kız tarafının erkek tarafina yaptığı ziyarettir. Bütün akrabaların katılabildiği törende kız tarafi içinde börek, tatlı, kuruyemiş, tavuk, et, şeker ve lokumların bulunduğu yedi çeşit sini hazırlar. Bu sinilerdeki yiyecekler, erkek tarafina hediye edilir ve erkek tarafının kadınları bu yiyeceklerden kız tarafina da ikram edilir (BKZ. Abalı, 2011: 67).

${ }^{15}$ Duvak töreni, köyde eskiden gelinin bekâretini kutlamak ve bunu köylüye duyurmak amaciyla gerdekten sonraki gün gerçekleştirilmekte iken günümüzde bu amaçtan ziyade gelinin ve kızların eğlenmesi gayesiyle düğünden sonraki Cuma günü yapılmaktadır (Daha geniş bilgi için BKZ. Köse, 2003; Abalı, 2011: 81). Aydın'ın bazı köylerinde bu uygulamaya “Kız Arkası" ismi verilmektedir (Aktakka@Demircan, 2006: 45).
} 
oturtulmasına Gözkaya köyünde büyük bir önem verilir ve aileler birbirlerini daha yakından tanımaya çalışır. Evlenecek gençlerden biri köy dışından ise karşı aileyi araştırma süreci daha uzun sürer. $\mathrm{Bu}$ araştırma süreci, karşı aileye de haber verilir ve bu durumdan rahatsız olup olmayacağı da sınanmış olur (K4, K6, K10).

* Kız istemede ya da önceden gidilen görücü ziyaretinde erkek tarafının kadınları, temizlik kontrolü yapabilir. Kaynak kişilere göre bu yöntemlerin en bilineni ve en iyi sonuç vereni, eldeki yumağın düşürülmüş gibi yapılıp divanın/koltuğun altına atılması ve geri çekilerek temiz olup olmadığının kontrol edilmesi yöntemidir (K7, K10).

* Evlenecek gençlerin ev eşyalarının nasıl, ne zaman ve kim tarafından alınacağı isteme esnasında konuşulur. Gözkaya köyünde genellikle çiftlerin yatak odası ve mutfağını kız tarafı, oturma ve misafir odasını erkek tarafı karşılar. Çocuk odası ise ortaklaşa yapılır (K2, K8, K11).

* Nişan töreninde kızın ve oğlanın çeyizleri, kız evine (varsa evlendikten sonra oturacakları başka bir eve) erkek tarafının kadınları tarafından serilir. Bu süreçte kız tarafı kesinlikle çeyizlere dokunamaz. Bu durum ayıp olarak karşılanır (K1).

* Düğünden önceki Cuma günü, sabah namazından sonra erkek tarafının evine Türk bayrağı dikilir. Damat bir gün önceden köydeki tüm evleri dolaşarak erkekleri bayrak dikmeye davet eder ve gelirken yanlarında silahlarını bulundurmasını söyler. Bayrak dikme töreninde damat ve diğer erkekler havaya ateş ederler. Silahların mermilerini damadın karş1lamas1 gerekmektedir (K2).

* Düğünden önce dikilen bayrak, gelin almaya gidilirken dügün ahalisinin önünde taşınır (Şekil-7). Bayrakçının gözü açık biri olmasına dikkat edilir. Zira kız tarafı bayrağı çalmaya çalışabilir. Bayrağın çalınması büyük bir ayıp olarak karşılanır. Gelin alma töreninden sonra bayrak ve bayrağın ucunda takılan yazma, mendil gibi hediyeler bayrakçıya verilir $(\mathrm{K} 3, \mathrm{~K} 7)$.

* Gelin alma töreninde erkek tarafı "gelin alıcılar, can alıcılar" olarak nitelendirilir ve kız tarafı gelini hemen vermek istemez. Gelinin evden çıkması uzun sürerse erkek tarafından bazı kişiler kız evinden tavuk, bakır çanak, çiçek gibi evin avlusunda bulduğu şeylerden çalabilir. Bu durum ayıp olarak karşılanmaz (K1, K8).

* Gelin alma töreninden sonra damat, gelinin getirildiği arabanın (eskiden at veya deve) etrafında üç defa tur attırılır. Damada türlü eziyetler yapılır: Uzak bir yerden altı delik bir bidonla su getirtmek, kadın kıyafetleri giydirilip kazanın üstünde oynatmak, çiğ yumurta yedirmek gibi... Gelin arabadan inerken üstüne çerez, şeker, buğday ve bozuk paralardan oluşan saçı atılır. Gelin indiğinde kaynanası zenginlik durumuna göre "indirmelik" adında bir hediye (inek, koyun, tarla, zeytinlik gibi) vermek zorundadır. Bu hediye hafif bulunursa köyün diğer kadınları, gelinin hakkını savunmak için kaynana ile pazarlık yapabilir (K6, K11).

\section{c. Ölüm/Cenaze İle İlgili Örf ve Âdetler}

* Gözkaya köyünde, ölen kişinin salasını imam verir ve imama bir miktar para verilmesi gerekir (K2).

* Köyde ölen kişinin cenazesi köyün camisinden getirilen tabutla taşınır. Cenazenin üstüne halı ve battaniye örtülür. Defin işleminden sonra bu halı ve battaniye camiye bağışlanır. Aksi takdirde evden daha çok ölü çıkacağına inanılır (K2). 
* Ölen kişinin oğlu ya da bir erkek yakını, ölü gömüldükten sonra mezarlığın dışında cemaate seslenerek merhumdan bir alacağ1 olanın kendisine haber vermesini söyler (K2, K4).

* Gözkaya köyünde, cenaze evinden ayrılanların kendi evlerine varmadan başka evlere gitmelerinin o evden de ölü çıkaracağı inanc1 mevcut olduğundan kimse cenazeden sonra misafirliğe gitmez; başkasını da kendi evine davet etmez (K1).

* Cenaze sahipleri, üç gün boyunca "Emir Allah'ın"a ("Başın sağ olsun" mahiyetinde söylenen bir söz) gelen misafirlerini uğurlarken "Buyurun gelin" demezler. Çünkü ölünün ruhunun üçüncü gün hayrı yapılana kadar evde kaldığına ve "Buyurun gelin" denirse yanında başkalarını da götürmek isteyeceğine, yani ölü sayısının artacağına inanılır (K10).

* Köyde yas geleneği canlı bir şekilde yaşatılmakta ve herkes buna riayet etmeye çalışmaktadır. Cenaze evinde kırk gün, köyde ise üç gün boyunca çamaşır yıkanmaz; ev süpürülmez, televizyon ve radyo açılmaz. Üç ay süreyle köyde düğün, nişan yapılmaz; ertelenir. Önceden tüm hazırlıklar yapılmış ise düğün, müzikli değil mevlitli yapılır (K1, K4).

* Gözkaya köyünde, ölen kişinin mirası çocukları (ölen çocuğunun yerine varsa eşi ve eşinin çocuklarının her biri) arasında eşit şekilde pay edilir. Malların paylaşımında özellikle de zeytinliklerde her bahçe, mirasçı sayısına göre bölünür ve kura ile bahçelerin hangi kısmının kime ait olduğu belli olur. Bu yöntemin tercih edilmesinde ürün verimliliği ile bahçenin yola yakınlığı esas alındığından yüksek verimli ve ulaşımı kolay olan bahçelerin bir tek kişiye kalmasının önüne geçilmiş olur. Hayvan, ev ve eşya gibi bölünmesi mümkün olmayan mallar ise göz kararı yoluyla ve her mirasçının olurunun alınması suretiyle pay edilir ve kura ile bölüştürülür. Bazı ailelerde bu durumun bir istisnası olarak baba ocağı sayılan ev, tarla ve zeytinlik -tüm mirasçıların da onayıyla- en küçük erkek kardeşe bırakılır. Çünkü en küçük kardeşin diğerlerine göre daha uzun yaşayacağı ihtimali bulunduğundan baba ocağına daha uzun bir süre sahip çıkacağına inanılır. Miras bölme işlemi çoğunlukla kişinin ölümünün sene-i devriyesinde yapılsa da mirasçıların ortak kararı ile daha erken bir tarihe de çekilebilmektedir. Gözkaya köyünde miras paylaşımı, genellikle yaşça en büyük mirasçının evinde yapılır. Miras paylaşımına kadınlar ve kızlar katılamaz; ancak kadın mirasçının kocası, ölmüssse oğlu ya da hakkını savunabileceğine inandığı güvenilir erkek bir akrabas1 kat1labilir (K1, K2, K4, K10).

\section{Sonuç}

Kaynak kişilerden elde edilen bilgilere göre Gözkaya köyünde halk hukuku bağlamında ortaya çıkan örf, âdet ve buna bağlı uygulamaların temelinde gelir kaybı ihtimalinin verdiği endişe, hakkını muhafaza etme, yardımlaşma arzusu, ayıplanma korkusu ve bereket, nazar gibi halk inanışlarının etkililiği bulunmaktadır. Özellikle hayvancılık ve zeytincilikle ilgili örf ve âdetlerde temel geçim kaynaklarından elde edilen gelirin kaybedilme tehlikesini barındıran durumları bertaraf etmek için gerçekleştirilen uygulamalar dikkate değerdir. Başıboş hayvanların tokada hapsedilme işlemi, bireyler arasındaki anlaşmazlıkları çözme ve kişisel hakkı koruma noktasında bu uygulamalardan biridir. Hayvanların ya da zeytinden elde edilen mahsulün veriminin azalması da köylünün gelir kaybına yol açmaktadır. Bunu nedenle bireyler, hayvanlarının ve zeytinlerinin bereketini azaltacağına inandıkları durumlardan da kaçınmaktadırlar. Satılan hayvanın bedeline ek olarak çoban salık verilmesi, yük hayvanlarına ait eşyaların kesinlikle satılmaması, sürünün ortasından yabancıların 
geçmesine izin verilmemesi ve bulunan çatal zeytin karşıllğında bahşiş istenmesi doğrudan bereket inancıyla ilgilidir. Halk hukuku kurallarının ortaya çıkmasındaki etkenlerden bir diğeri de ayıplanma korkusudur. Bu nedenle misafir ağırlayan ev sahibinin yapması ve yapmaması gereken davranışların her biri halk hukuku kurallarına dönüşmüştür. 


\section{KAYNAKÇA}

ABALI, İsmail (2011). Koçarlı Halk Kültürü, Aydın: Adnan Menderes Üniversitesi Sosyal Bilimler Enstitüsü Basılmamış Yüksek Lisans Tezi.

ABALI, İsmail (2014). "Meslek Folkloru Bağlamında Zeytincilik (Gözkaya Köyü/Aydın Örneği)", ulakbilge, 2 (3), 115-139.

AKTAKKA, Nuri\&DEMIRCAN, M. Necati (2006). Dünden Bugüne Aydın Halk Kültürü, Ankara: Kültür ve Turizm Bakanlığı Yayınları.

BERGSON, Henri (2013). Ahlakın ve Dinin İki Kaynağı, (Çev: M. Mukadder Yakupoğlu), (2. Basım), Ankara: Doğubatı Yayınları.

BORATAV, Pertev Naili (1973). 100 Soruda Türk Folkloru, İstanbul: Gerçek Yayınevi.

Derleme Sözlüğü V (E-F) (1993). Ankara: TDK Yayınları.

Derleme Sözlü̆̆̈̈ X (S-T) (1993). Ankara: TDK Yayınları.

Derleme Sözlüğ̈̈ XI (U-Z) (1993). Ankara: TDK Yayınları.

DUNDES, Alan\&Dundes, Alison (1994). Folk Law, New York and London.

DURSUN, Aysun (2014). Türk Halk Kültüründe Hukuk Kavramı, Muğla: Muğla Sitk1 Koçman Üniversitesi Sosyal Bilimler Enstitüsü Basılmamış Doktora Tezi.

GÖKBEL, Ahmet (1998). Anadolu Varsaklarında Inanç ve Adetler, Atatürk Yüksek Kurumu Atatürk Kültür Merkezi Yayınları, Sayı: 158.

KÖSE, Nerin (2003). “Türk Dügü̈nlerinde Gerdek Sonrası Duvak Geleneği”, Milli Folklor, S. $60,92-109$.

MALINOWSKI, Bronislaw (1998). Illkel Toplum, (Çev: Hüseyin Portakal), Ankara: Öteki Yayınevi.

ÖGEL, Bahaeddin (1978). Türk Kültür Tarihine Giriş II, Ankara: Kültür Bakanlığı Yayınlar1.

Türkçe Sözlük (2005), Ankara: Türk Dil Kurumu Yayınları.

ÖNDER, Ali Rıza (1976). "Geleneksel Halk Hukuku”, I. Uluslararası Türk Folklor Kongresi Bildirileri, C. IV, 225-240.

ÖRNEK, Sedat Veyis (1995). Türk Halkbilimi, Ankara: Kültür Bakanlığı Yayınları.

SEVİNDIK, Azem (2013). Halk Hukuku ve Köy Odaları: Sivas Şarkışla Gümüştepe Köyü Örneği, Ankara: Hacettepe Üniversitesi Sosyal Bilimler Enstitüsü Basılmamış Yüksek Lisans Tezi.

\section{Kaynak Kişiler:}

K1: Hasibe Abal1, 55 yaşında, ilkokul mezunu, Gözkaya doğumlu, Görüşme T.: 26.04.2018

K2: Celal Abalı, 58 yaşında, ilkokul mezunu, Gözkaya doğumlu, Görüşme T.: 26.04.2018

K3: Salih Nizam, 69 yaşında, ilkokul mezunu, Gözkaya doğumlu, Görüşme T.: 03.05.2018

K4: Süleyman Küçük, 81 yaşında, ilkokul mezunu, Gözkaya doğumlu, Görüşme T.: 02.05.2018 
K5: Ömer Ak, 86 yaşında, ilkokul mezunu, Gözkaya doğumlu, Görüşme T.: 29.04.2018

K6: Asiye Koca, 77 yaşında, okuma-yazma yok, Gözkaya doğumlu, Görüşme T.: 06.05.2018

K7: Emine Abal1, 31 yaşında, ortaokul mezunu, Esentepe doğumlu, Görüşme T.: 26.04.2018

K8: Burhan Yeniçeri, 54 yaşında, ilkokul mezunu, Gözkaya doğumlu, Görüşme T.: 03.05.2018

K9: Ömer Ali Abalı, 12 yaşında, öğrenci, Gözkaya doğumlu, Görüşme T.: 26.04.2018

K10: Emine Özçelik, 61 yaşında, okuma-yazma yok, Gözkaya doğumlu, Görüşme T.: 06.05.2018

K11: Elif Yeniçeri, 45 yaşında, ilkokul mezunu, Gözkaya doğumlu, Görüşme T.: 03.05.2018 


\section{EKLER (FOTOĞRAFLAR)}

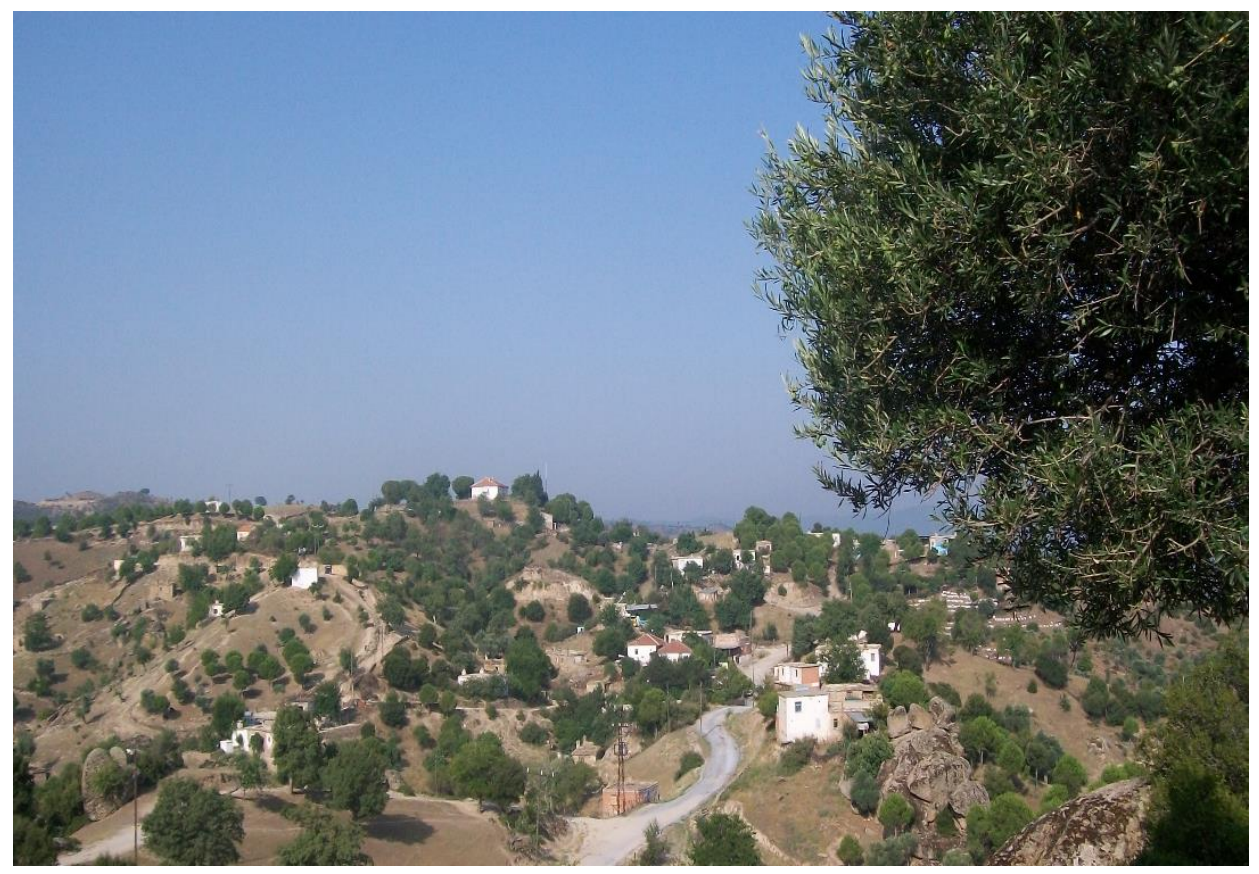

Şekil-1: Gözkaya köyü merkez mahallesinin genel görünümü

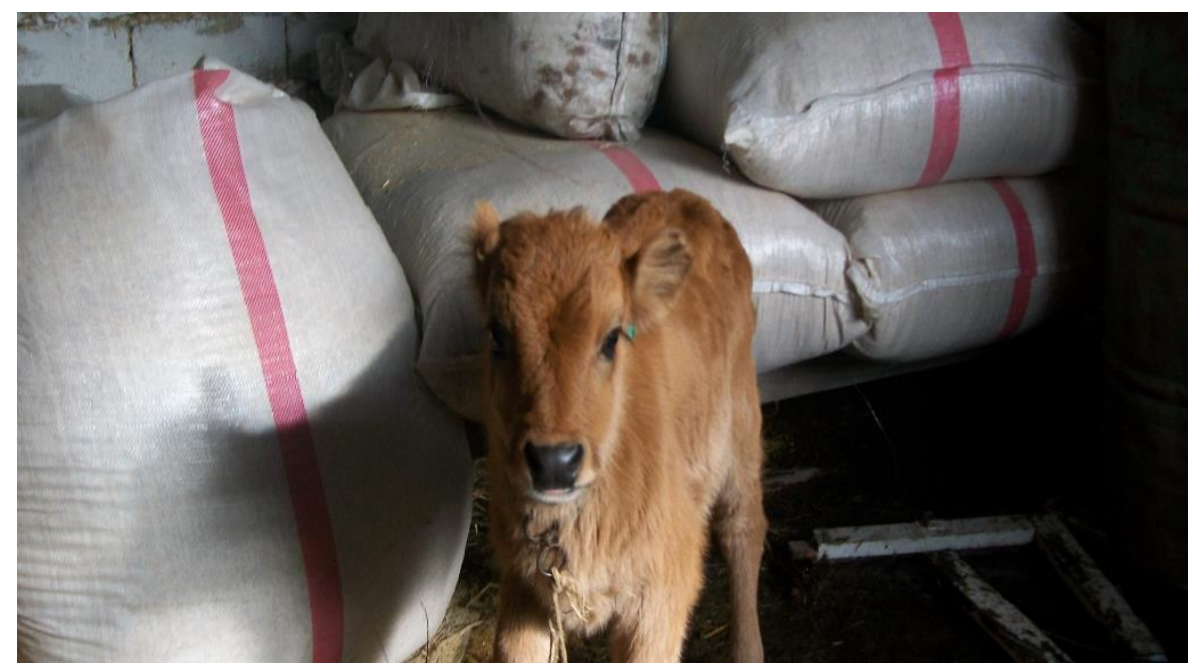

Şekil-2: Kulağının ucundan ennenmiş bir buzağı 


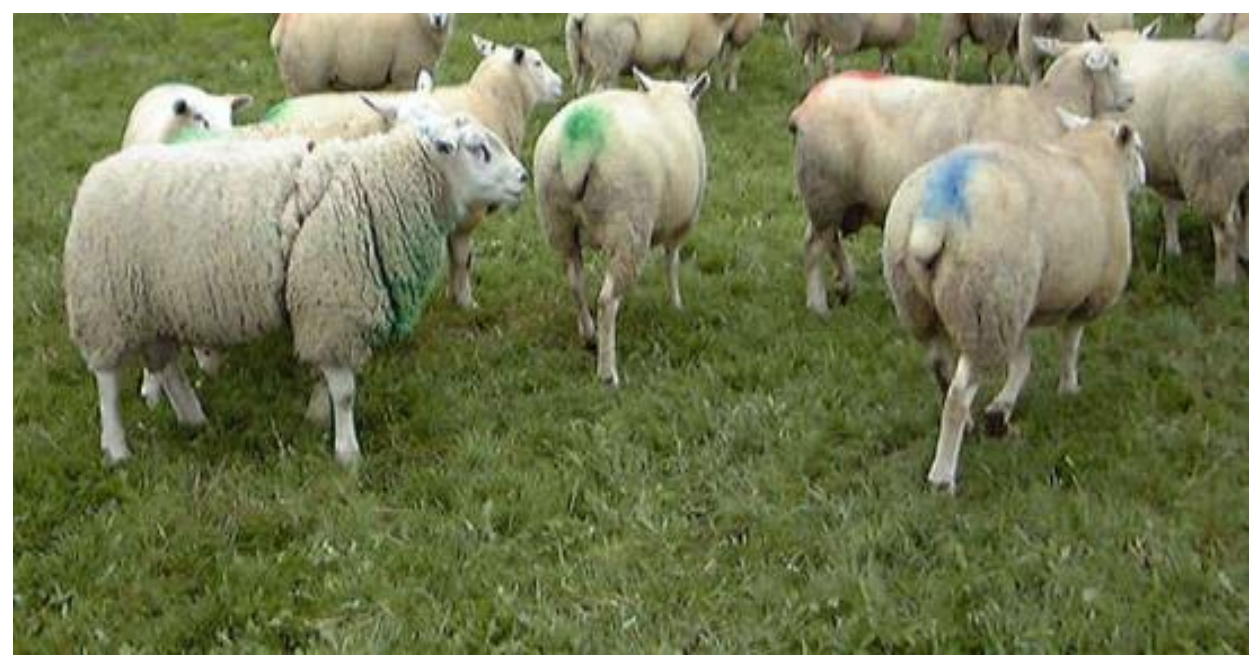

Şekil-3: Boya ile ennenen koyunlar

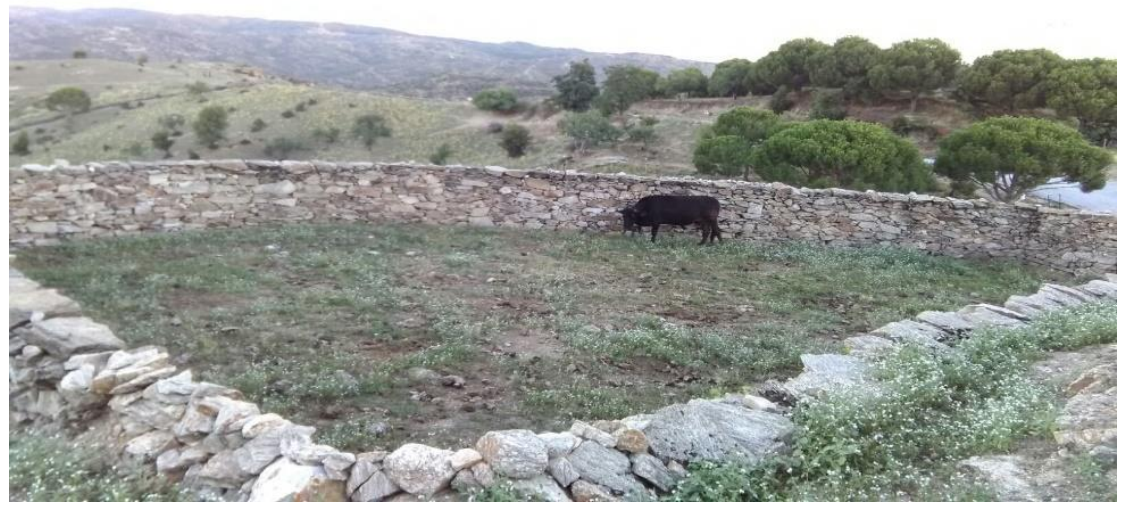

Şekil-4: Tokat

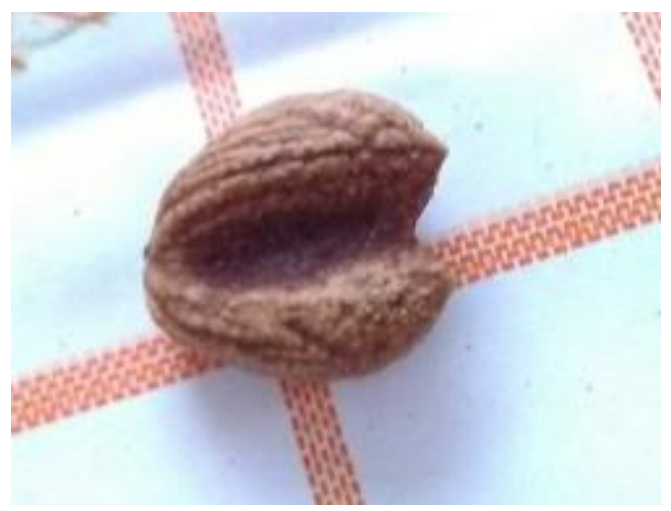

Şekil-5: Çatal zeytin çekirdeği 


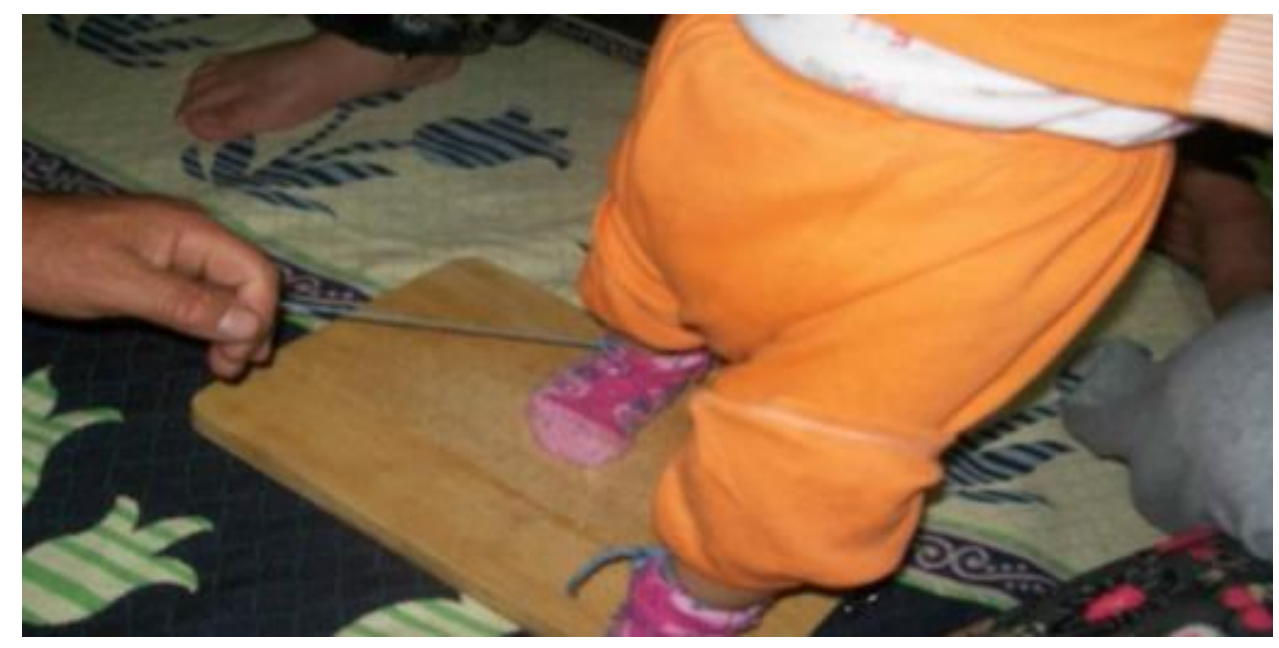

Şekil-6: Duşak kesme âdeti

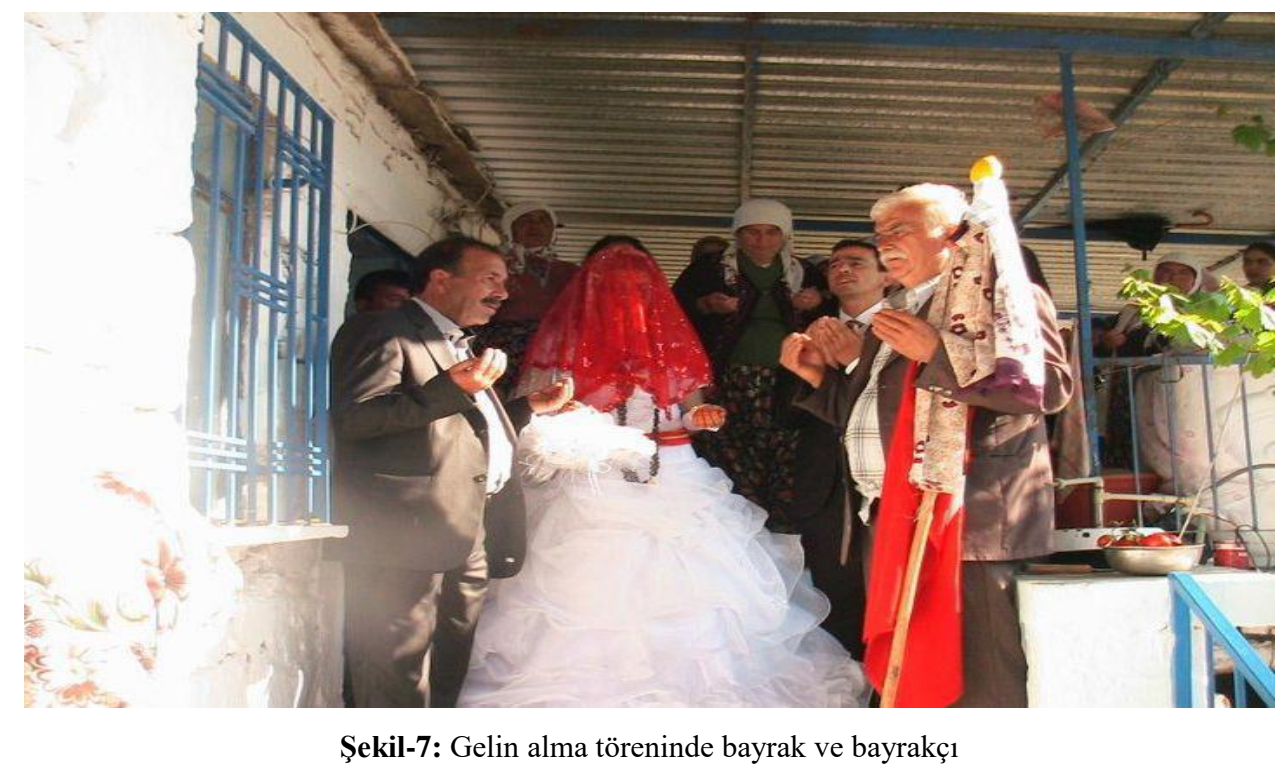

